\title{
Research on China's Tourism: A 35-Year Review and Authorship Analysis
}

\author{
LINA ZHONG ${ }^{1}$, BIHU WU² and ALASTAIR M. MORRISON ${ }^{3 *}$ \\ ${ }^{1}$ School of Tourism Management, Beijing International Studies University, Beijing, China \\ ${ }^{2}$ Center for Recreation and Tourism Research, Peking University, Beijing, China \\ ${ }^{3}$ School of Hospitality and Tourism Management, Purdue University, West Lafayette, IN, USA
}

\begin{abstract}
This study reviewed 333 articles on China's tourism from 96 English-language academic journals within and outside of tourism from 1978 to 2012. Tourism policy and impacts, and tourism industry development and promotion were the two predominant research themes. Tourism development, policy, ecological impacts, attractions and markets were the five most popular topics. On the basis of an authorship relationship analysis, three research networks were producing most of the China tourism research output in English. A majority of the authors were based in Mainland China, the USA and Hong Kong. Trends and gaps in the literature on China's tourism were identified.
\end{abstract}

\section{BACKGROUND ON CHINA’S TOURISM}

China has experienced dramatic economic growth in the 35 years since the Open Door Policy was introduced in 1978. China's tourism industry is one of the fastest-growing in the national economy. From 2000 to 2011, the total revenues of China's tourism increased by 36 per cent annually (China National Tourism Administration, 2002, 2012). It is forecasted by the UN World Tourism Organization that China's tourism industry will represent an 8.6 per cent share of the worldwide tourism market and will rank as the world's top tourism industry by 2020 (UNWTO, 2009). China's tourism has drawn increasing attention not only from domestic and overseas investors for its business opportunities but also from academic researchers in Mainland China and abroad. The rapid growth of tourism in China has been accompanied by a surge in the tourism research literature. Several Englishlanguage books (Lew et al., 2003; Ryan and Gu, 2009) and many articles published in international research journals (Zhang et al., 2000; Pine, 2002; Li et al., 2010) have focused on tourism in China.

China's remarkable development growth history has attracted global research attention across a wide set of fields including tourism. The rapid expansion of Chinese tourist markets has particularly drawn the attention of tourism researchers and marketers; e.g. China has become the largest source market of outbound tourism within Asia (Li et al., 2010). Outside of Asia, China is now a major tourist-generating market source for several countries; e.g. it was the second top source of international visitors in 2012 for both Australia and New Zealand (Australian Bureau of Statistics, 2013; Statistics New Zealand, 2013). For 2011, there were 70.3 million outbound trips by Chinese, and the China Tourism Academy estimated an increase

* Correspondence to: Alastair M. Morrison, Distinguished Professor Emeritus, School of Hospitality and Tourism Management, Purdue University, 900 W. State Street, West Lafayette, IN, USA.

E-mail: alastair@purdue.edu to 83 million for 2012. In addition, China has a huge domestic tourist market comprising 2.641 billion trips in 2011 (China National Tourism Administration, 2012). After declines in inbound tourist arrivals in 2008 and 2009, China experienced renewed growth in 2010 and 2011; inbound trips totaled 13.54 million in 2011 (China National Tourism Administration, 2012). Given these unique circumstances, China is perhaps on its way to becoming the world's greatest 'tourism laboratory', where researchers are able to test, monitor and confirm or refute some of the tourism industry's most widely held assumptions (Wang et al., 2010).

\section{REVIEWS AND META-ANALYSES IN TOURISM}

Reviews and meta-analyses have made a great contribution to the research on various aspects of tourism. Dann et al. (1988) presented a meta-analysis of 229 articles published in Annals of Tourism Research from 1974 to 1986. Cooper (2003), in his book Classic Reviews in Tourism, provided reviews by several contributors on broad themes, including the sociology of tourism, economics of tourism, statistical measurement of tourism, temporal change and the history of tourism and recreation, marketing of the service process, urban tourism, alternative tourism, gender and tourism, and other themes. Other researchers have focused on more specific topics to provide a comprehensive understanding of the accumulated scholarship in narrower aspects of tourism. Crouch (1995) completed a meta-analysis of 80 studies on international tourism demand. Baaijens et al. (1998) prepared an explanatory meta-analysis on regional tourist income multipliers. Weber (2001) reviewed the research approaches employed in outdoor adventure tourism; she concluded that previous research was too narrowly focused and needed to be broadened so as to gauge the full size and potential of adventure tourism. Pike (2002) reviewed 142 articles on destination image published from 1973 to 2000. 
Baum (2007) reviewed the key themes for the roles and management of human resources in tourism. Weed (2009) studied previous research on sports tourism, covering topics such as core concepts and dominant research areas, and reflected on the strengths and weaknesses and future maturation of sports tourism research. Park and Gretzel (2007) produced a qualitative meta-analysis of the success factors of destination websites; later, Law et al. (2010) analyzed website evaluation approaches in tourism research. Many more examples of reviews and metaanalysis in tourism could be cited, but it suffices to say that there is a rich history of such reporting of the scholarship of tourism for at least the past 25 years.

These extended literature reviews and meta-analyses have allowed tourism researchers to acquire more in-depth knowledge of specific themes and topics, as well as better grasping the trends in scholarly contributions for particular periods. Moreover, these analyses have been helpful in identifying gaps in the accumulated tourism literature to date. Above all, they are invaluable resources for researchers for guiding future research inquiries.

\section{REVIEWS OF RESEARCH ON CHINA'S TOURISM}

Inevitably, China's tourism has become a popular research field for scholars within and outside of Mainland China. Several researchers have attempted to review the growing body of scholarship about China's tourism. Most of these reviews have been published in Chinese within journals in Mainland China that are not well known to or can be read by the international academic community (Aramberri and Xie, 2003; Xie, 2003). However, several reviews have been published in English (Huang and Hsu, 2008; Kong and Cheung, 2009; Hsu et al., 2010; Tsang and Hsu, 2011).

Huang and Hsu (2008) reviewed 500 articles in Tourism Tribune from 2000 to 2005 to better understand the research on China's tourism and found that tourism attraction/resources development, management and protection, tourism planning and macro issues on tourism industry development were the most popular topics. These two authors cited a number of previous review studies, mostly completed by scholars in Mainland China, of the tourism literature in Chinese-language academic tourism journals. They found that their results about topics were very consistent with those of a previous study by Song et al. (2005), who reported the most popular topics as the tourism development situation and trends; regional tourism development, tourism planning and development; and tourism resources preservation, ecotourism and sustainable development. The Song et al. (2005) study reviewed 481 articles in Tourism Tribune from 2000 to 2004; all of which were published in Chinese. Huang and Hsu (2008) noted that a study by Zhang (2004) found that the research on China's tourism was lagging behind international tourism research; in particular, international researchers were paying more attention to demand-side issues, whereas Chinese researchers mostly focused on supply-side issues. Huang and Hsu (2008) concluded that tourism scholars in Mainland China also needed to learn more from their international counterparts in the application of research methods.
Kong and Cheung (2009) reviewed 66 refereed journal articles published from 1984 to 2007 on the development of China's hotel industry. The two authors searched three large databases to identify the articles that satisfied their criteria. They grouped the articles into four major themes: strategy and development, marketing, service quality and human resources management. Strategy and development was the most popular theme, accounting for 43 per cent of the articles. The fields of study, major concepts/variables and methodology (conceptual, qualitative or quantitative) were analyzed for each article. The authors concluded that there was a need for more research on human resources management, emerging trends and new developments, marketing and service quality.

Tsang and Hsu (2011) set a new benchmark for reviews on China's tourism research by analyzing 119 articles from 1978 to 2008 in six top English-language journals: Cornell Hospitality Quarterly, International Journal of Hospitality Management, Journal of Hospitality and Tourism Research, Annals of Tourism Research, Tourism Management and Journal of Travel Research. The two researchers only selected peer-reviewed full-length articles that met their criteria. The analysis of articles included research themes, disciplines, institutional contributions, authorship information and research methods. The authors identified 13 themes in the articles: tourism development, consumer behavior, hotel development, education and training, business management, ecotourism, service quality, tourism policy, destination image, hotel rating systems, human resources, websites and others. The largest share of the articles $(37.8 \%)$ was for the tourism development theme. Consumer behavior $(17.7 \%)$ and hotel development (10.9\%) were the second and third most popular themes.

These reviews of the progress and status of China's tourism research have helped researchers to much better understand the tourism research situation as well as the country's tourism development. However, by their own statements of limitations, these studies have reviewed the progress of China's tourism research in a limited pool of the leading Chinese and international tourism and hospitality journals (Huang and Hsu, 2008; Kong and Cheung, 2009; Tsang and Hsu, 2011). As a result, these reviews have produced an incomplete analysis of China-related tourism research. Many unaccounted for articles reporting on studies of China's tourism have been published in other refereed tourism and hospitality journals, and authors have published research articles in journals of other fields, such as psychology and marketing (Jogaratnam et al., 2005). A broader and more in-depth review is needed to provide a more comprehensive and balanced understanding of the current state of the research on China's tourism.

Most of the aforementioned reviews focused on research themes, disciplines, institutional contributions, authorship information and research methods (Sheldon, 1991; Jogaratnam et al., 2005). The identification of articles included journal titles, years of publication, names of authors, authorship information (including gender, age, education, author types, regions and single author versus co-author) and institutions of the authors. The previously published reviews of China's tourism research have provided a good preliminary snapshot 
but have not delivered a comprehensive review of China tourism research topics. In addition, they have generally not reported on the changing trends in research topics or the authorship networks of China tourism researchers. To address these limitations, this study aims to

(1) pinpoint international academic journals publishing articles of research on China's tourism;

(2) identify scholars who have authored research articles on China's tourism;

(3) describe the relationships and networks of authors publishing research on China's tourism;

(4) content analyze the research articles on China's tourism and determine the predominant themes and topics therein; and

(5) determine the trends and any gaps in the research on China's tourism.

\section{METHODOLOGY}

\section{Data collection}

A careful study of 19 review articles from Annals of Tourism Research and Tourism Management showed that tourism researchers preferred to use databases and specific journals to gather articles for review purposes. The Web of Science, EBSCOhost, Emerald Management Review, Science Direct, Google Scholar and CABI were the most used databases, and Annals of Tourism Research, Tourism Management and Journal of Travel Research were the most searched journals. To get a broader view of the scholarship on China's tourism, this research study analyzed multiple databases to gather related articles rather than combing through specific journals. ISI Web of Science (www.isiknowledge.com), Science Direct (http://www.sciencedirect.com) and EBSCOhost (http://search.ebscohost.com) were chosen for their international recognition and authoritativeness. Wiley InterScience (http://www3.interscience.wiley.com/) and SAGE journals online (http://online.sagepub.com/) were chosen for their exclusive selection of some globally famous tourism journals such as Journal of Travel Research, Cornell Hospitality Quarterly and International Journal of Tourism Research. The timeframe was limited to papers published from 1978 to 2012 to assess the progress of Chinese tourism research since the country opened its doors in 1978.

Data were collected through a search of relevant articles within the databases on 3-9 January 2013. A total of 253 articles were found by using 'tourism' and 'China' in the 'academic journals' section of ISI Web of Science. Two hundred fifty two and 62 articles were located by searching 'tourism' and 'China' in the abstracts of Science Direct and SAGE journals online respectively. By using the keywords 'China' and 'tourism', 150 articles were identified using Academic Search Premier of EBSCOhost, and 32 additional papers were obtained on Wiley InterScience. Overall, 272 articles were found in the different databases after eliminating the duplicates. Although the articles were selected carefully, there were still some editors' comments, readers' comments, research notes, book reviews and articles of which the main topics were about other subjects rather than tourism or they were not China focused. All these records were eliminated to maintain the focus on the academic development of China's tourism research. On the basis of these criteria, a total of 333 articles were retained in the database for further analysis.

\section{Data analysis}

Data were analyzed and classified in three main stages. The first stage involved a content analysis of the selected articles. Publication years, authors and institutional affiliations were coded and analyzed by tabulating them into selected categories. The order of authorship was not recorded; if there were multiple authors, each author was given the same credit as a researcher publishing as a sole author. It should be noted that the quality of the selected articles was not assessed. Thus, the research productivity and centrality ranks of researchers reported in this study were only based upon quantitative measurement.

Second, social network analysis was applied to analyze authorship relationships, and the collaboration among researchers was measured using UCINET software (Analytic Technologies, Harvard, MA). The centrality and power of the authorship networks were calculated. Significant network characteristics and the sociology behind their significance were noted.

Third, the selected articles were classified into dominant thematic categories, following the approach proposed by Miles and Huberman (1994), which emphasized three flows of analytical activity: data reduction, data display and verification of the data. At the data reduction stage, a 'word count' technique was adopted. A content analysis of each journal title was completed, and then the full paper was accessed to classify it into a category, as established through the word count. On the basis of the reduction work, it was initially proposed that there were three broad theme categories: tourist markets (demand), tourism industry development and promotion (supply), and policy and tourism impacts (external environment) (Cook et al., 2010). Subcategories were defined as research topics. This methodological approach allowed tabulation and visualization of data at the early stage of the research, and initial tentative formulation of the prevalent themes and emerging trends in research topics. To refine the setting of topic subcategories, abstracts, first paragraphs and as much text from relevant sections as needed were read to place articles into the appropriate subcategories (Crawford and McCleary, 1992). This allowed further development of the classification of subcategories and, consequently, verification of the findings.

\section{RESEARCH RESULTS}

\section{Overview of articles published on China's tourism in English}

The procedures produced a sample of 333 articles that met the preset criteria of English-language articles published in refereed international journals. Table 1 indicates that research on China's tourism increased from 1978 to 2012, and especially since 2000. Moreover, more than half $(61.6 \%)$ of the articles were published 
Table 1 . Number of articles by publication year and period

\begin{tabular}{|c|c|c|}
\hline Publication year & Number of articles & $\%$ \\
\hline \multicolumn{3}{|l|}{ 1978-1990 } \\
\hline 1979 & 1 & 0.3 \\
\hline 1983 & 3 & 0.9 \\
\hline 1985 & 3 & 0.9 \\
\hline 1986 & 2 & 0.6 \\
\hline 1987 & 3 & 0.9 \\
\hline 1988 & 2 & 0.6 \\
\hline 1989 & 5 & 1.5 \\
\hline 1990 & 1 & 0.3 \\
\hline Subtotal & 20 & 6.0 \\
\hline \multicolumn{3}{|l|}{ 1991-2000 } \\
\hline 1991 & 3 & 0.9 \\
\hline 1992 & 2 & 0.6 \\
\hline 1993 & 4 & 1.2 \\
\hline 1994 & 3 & 0.9 \\
\hline 1995 & 4 & 1.2 \\
\hline 1996 & 4 & 1.2 \\
\hline 1997 & 3 & 0.9 \\
\hline 1998 & 4 & 1.2 \\
\hline 1999 & 4 & 1.2 \\
\hline 2000 & 2 & 0.6 \\
\hline Subtotal & 33 & 9.9 \\
\hline \multicolumn{3}{|l|}{ 2001-2010 } \\
\hline 2001 & 1 & 0.3 \\
\hline 2002 & 7 & 2.1 \\
\hline 2003 & 4 & 1.2 \\
\hline 2004 & 10 & 3.0 \\
\hline 2005 & 12 & 3.6 \\
\hline 2006 & 18 & 5.4 \\
\hline 2007 & 23 & 6.9 \\
\hline 2008 & 31 & 9.3 \\
\hline 2009 & 22 & 6.6 \\
\hline 2010 & 44 & 13.2 \\
\hline Subtotal & 172 & 51.6 \\
\hline \multicolumn{3}{|l|}{ 2011-2012 } \\
\hline 2011 & 59 & 17.7 \\
\hline 2012 & 49 & 14.7 \\
\hline Subtotal & 108 & 32.4 \\
\hline Total & 333 & 99.9 \\
\hline
\end{tabular}

in the five years from 2008 to 2012. Figure 1 clearly illustrates this trend of growing research interest in China's tourism.

\section{Journals including publications of research on China's tourism}

The first objective of this study was to identify the academic journals publishing research articles on China's tourism. Some 224 articles were published in tourism and hospitality journals; the remaining 109 appeared in business, marketing and sociology journals. It was to be expected that tourism and hospitality journals would have more interest in China's tourism research. Table 2 shows the numbers of the articles published in tourism and hospitality journals. Tourism Management, Annals of Tourism Research, International Journal of Hospitality Management and International Journal of Tourism Research were the four journals with the most articles on China's tourism, accounting for almost 40 per cent of all the identified articles.

The nontourism and hospitality journals published a significant 32.7 per cent of all the articles on China's tourism.
This verified the research team's proposition that it was essential to review such scholarship outside of the tourism and hospitality journals. Journals related to economics, ecology, environment, anthropology and geography demonstrated the greatest interest in research on China's tourism (Table 3).

\section{Author productivity and authorship relationships}

This study's second objective was to identify scholars who had authored research articles on China's tourism. A total of 778 author names were associated with the 333 articles, and there were 556 individual authors. Of the 333 articles, $93(27.9 \%)$ were sole authorships, and $240(72.1 \%)$ were multiple authorships. Specifically, 111 articles $(33.3 \%)$ had two authors, $87(26.1 \%)$ had three authors, $26(7.8 \%)$ had four authors and $16(4.5 \%)$ had five or more authors.

Among the 556 authors, $448(80.6 \%)$ contributed to only one article, whereas the remaining 108 (19.4\%) authored two or more articles. Among the authors with multiple contributions, 52 had two, 22 had three, 16 authors had four and 7 had five articles. The most prolific authors were $\mathrm{Gu}, \mathrm{H}$. M., Law, R. and Bao, J. G., each with 6; Huang, S. S., with 7; Ryan, C. and Zhang, H. Q., with 11; and Wall, G., with 14 articles (Table 4).

The third objective was to describe the relationships and networks of authors publishing research on China's tourism. The research and authoring collaboration among authors was analyzed through network analysis software. Three strong authorship networks were detected, and these are shown in Figure 2. One was centered by $\mathrm{Wu}, \mathrm{B}$., a professor at Peking University, who co-authored with researchers within Mainland China and abroad. The second was centered by Huang, S. S., a professor at the University of South Australia, who co-authored with researchers in Hong Kong, Mainland China and other countries. The third network was centered by Zhang, H. Q., a professor at The Hong Kong Polytechnic University. She co-authored with researchers in Hong Kong, Mainland China and abroad; and her research network was the most extensive one with a focus on China's tourism. The important role of Hsu, C. H. C., a professor at The Hong Kong Polytechnic University, as a 'connector' among these three networks must also be noted.

\section{Author regions and university affiliations}

Table 5 shows that the authors were from 24 regions across the world. The largest group was authors from Mainland China $(n=319)$. Authors based in the USA $(n=156)$ and Hong Kong $(n=104)$ ranked second and third in frequency. Authors based in Australia, Taiwan, the UK, Canada and New Zealand also made significant contributions to the scholarship on China's tourism.

The Hong Kong Polytechnic University accounted for the largest number of these authors $(n=86)$. The second largest group was from the Chinese Academy of Sciences $(n=47)$, and the University of Waterloo $(n=28)$ in Canada was third. The top 10 universities in terms of author frequency were in Hong Kong, Mainland China, USA, Canada, Australia and New Zealand (Table 6). 


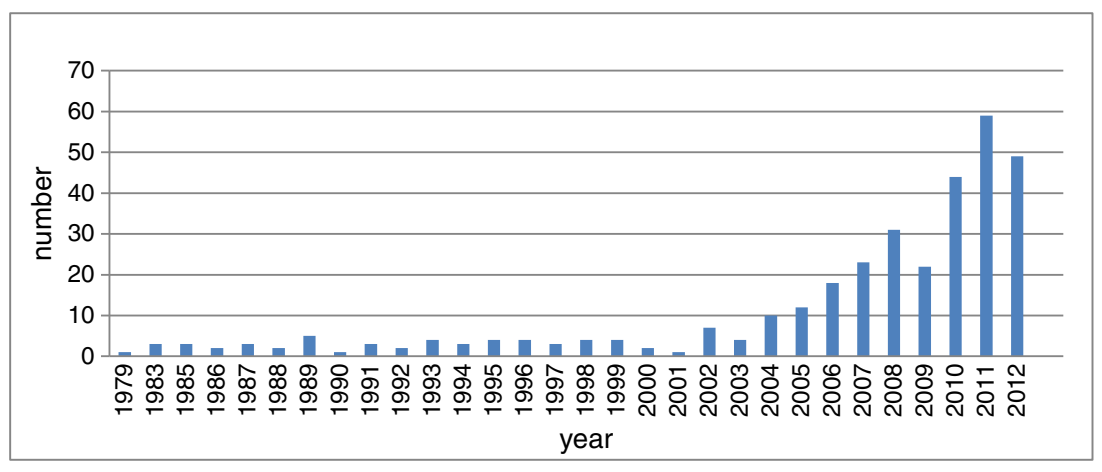

Figure 1. Numbers of articles by year of publication.

Table 2. Tourism and hospitality journals publishing articles on China's tourism

\begin{tabular}{lr}
\hline Names of journals (24) & N \\
\hline Tourism Management & 64 \\
Annals of Tourism Research & 32 \\
International Journal of Hospitality Management & 21 \\
International Journal of Tourism Research & 15 \\
Journal of Vacation Marketing & 14 \\
Tourism Geographies & 9 \\
Journal of Sustainable Tourism & 8 \\
Journal of Travel Research & 8 \\
Cornell Hospitality Quarterly & 7 \\
Journal of Travel \& Tourism Marketing & 6 \\
Asia Pacific Journal of Tourism Research & 5 \\
Journal of Hospitality \& Tourism Research & 5 \\
Journal of Teaching in Travel \& Tourism & 5 \\
Tourism Management Perspectives & 5 \\
International Journal of Contemporary & 4 \\
Hospitality Management & 3 \\
Journal of Tourism and Cultural Change & 3 \\
Tourism Economics & 2 \\
Journal of Convention \& Event Tourism & 2 \\
Journal of Hospitality Leisure Sport \& Tourism Education & 2 \\
Journal of Quality Assurance in Hospitality \& Tourism & 1 \\
International Journal of Hospitality \& Tourism Administration & 1 \\
Journal of Destination Marketing \& Management & 1 \\
Journal of Hospitality Marketing \& Management & 1 \\
Journal of Human Resources in Hospitality \& Tourism & 224 \\
Total &
\end{tabular}

\section{Research themes and topics}

The fourth study objective was to describe the predominant research themes and topics within the selected articles. Content analysis of the selected articles identified 20 research topics, and these 20 topics were grouped under three main themes: tourist markets, tourism industry development and promotion, and tourism policy and impacts. Some articles had a very broad research focus and were difficult to label. However, each article was eventually classified into one topic on the basis of its most significant focus.

Among the three research themes, tourism policy and impacts $(n=139)$ and tourism industry development and promotion $(n=129)$ accounted for most of the research articles. It was noteworthy that the third theme of tourist markets $(n=65)$ was given significantly less coverage by authors. As shown in Table 7, the top five tourism research topics were tourism development, tourism policy, ecological impacts of tourism, tourism attractions and tourist markets.

The expansion of China's tourism has been rapid, so the major focus of research has become how to develop the industry. Many research studies addressed the present situation of China's tourism development, how to promote the advancement of China's tourism, how to tackle numerous problems occurring during the tourism development process, and probable future growth trends.

Additionally, there has been considerable research attention to tourism policy and the ecological impact of tourism growth. With strong government involvement in China's tourism development, research on tourism policy has attempted to incorporate distinctive Chinese characteristics on the one hand, while adopting ideas from the development of international tourism on the other hand. Research on policy has consistently been a popular focus for tourism research on China, especially in special areas (e.g. Taiwan, Hong Kong, Russian border and Tibet). Moreover, the ecological impacts of China's burgeoning tourism have gained more attention from researchers. This greater priority to sustainable development approaches parallels the situation in other parts of the world. The rapid expansion of tourist volumes and great scale of tourism development threaten vulnerable ecological environments and precious heritage resources. How to confront these threats and resolve the paradox between development and conservation is not only a conundrum for China but also of practical significance for all developing countries that depend on tourism as economic driving force.

Significant research attention was given to tourism attractions. This is because tourism attractions in China are generally very profitable and generate significant amounts of cash and jobs. The management and development of tourism attractions in China differ from those of other countries. Tourism promotion and marketing research also seems to be increasing. However, compared with those countries in which tourism is more mature, there is a lack of research on promotion and marketing in China in terms of both quantity and thoroughness. This is likely to be a key topic in research on China's tourism in the future.

There were also significant numbers of articles on markets, accommodation, social impacts of tourism, community, education, services, economic impacts of tourism, destination images and technology. Other research topics including flows, segments, motives, events and food attracted more modest research attention (each with less than nine articles 
Table 3. Nontourism and hospitality journals publishing articles on China's tourism

\begin{tabular}{|c|c|c|c|}
\hline Journal names (36) & $N$ & Journal names (36) & $N$ \\
\hline Chinese Geographical Science & 11 & Environmental Conservation & 1 \\
\hline Energy Procedia & 9 & Environmental Monitoring and Assessment & 1 \\
\hline Environmental Management & 5 & East Asia: An International Quarterly & 1 \\
\hline Journal of Mountain Science & 4 & Forest Policy and Economics & 1 \\
\hline Anthropology News & 3 & Geography & 1 \\
\hline China Economic Review & 2 & Geoforum & 1 \\
\hline Geografiska Annaler Series B-Human Geography & 2 & Human Organization & 1 \\
\hline Habitat International & 2 & IERI Procedia & 1 \\
\hline International Journal of Information Management & 2 & Indoor and Built Environment & 1 \\
\hline Journal of Asian Architecture and Building Engineering & 2 & International Journal of Cultural Studies & 1 \\
\hline Journal of Environmental Management & 2 & International Journal of Heritage Studies & 1 \\
\hline Journal of Geographical Sciences & 2 & International Journal of Primatology & 1 \\
\hline Mathematics and Computers in Simulation & 2 & $\begin{array}{l}\text { International Journal of Sustainable Development and } \\
\text { World Ecology }\end{array}$ & 1 \\
\hline Procedia Environmental Sciences & 2 & International Journal of Urban and Regional Research & 1 \\
\hline Society \& Natural Resources & 2 & Journal of Asia-Pacific Business & 1 \\
\hline ACTA Botanica Sinica & 1 & Journal of Business Research & 1 \\
\hline ACTA Ecologica Sinica & 1 & Journal of Contemporary Asia & 1 \\
\hline ACTA Geographica Slovenica-Geografski Zbornik & 1 & Journal of Earth Science & 1 \\
\hline American Journal of Bioethics & 1 & Journal of Employment Counseling & 1 \\
\hline Anthropology of Work Review & 1 & Journal of Environmental Informatics & 1 \\
\hline Applied Economics Letters & 1 & Journal of Macromarketing & 1 \\
\hline Asia Pacific Journal of Anthropology & 1 & Journal of Sport Management & 1 \\
\hline Ballettanz & 1 & Lakes \& Reservoirs: Research \& Management & 1 \\
\hline Biological Conservation & 1 & Medical Anthropology & 1 \\
\hline China: An International Journal & 1 & Modern China & 1 \\
\hline China \& World Economy & 1 & Mountain Research and Development & 1 \\
\hline Chinese Economic Studies & 1 & Ocean \& Coastal Management & 1 \\
\hline Chinese Sociology and Anthropology & 1 & Physics Procedia & 1 \\
\hline Clinical Transplantation & 1 & Plos One & 1 \\
\hline Cultural Geographies & 1 & Procedia Engineering & 1 \\
\hline Computers in Human Behavior & 1 & $\begin{array}{l}\text { Proceedings of the Institution of Civil Engineers- } \\
\text { Municipal Engineer }\end{array}$ & 1 \\
\hline Cross-Cultural Communication & 1 & Progress in Human Geography & 1 \\
\hline Ecology and Society & 1 & Renewable and Sustainable Energy & 1 \\
\hline Ecological Indicators & 1 & Systems Engineering Procedia & 1 \\
\hline Energy Policy & 1 & $\begin{array}{l}\text { Tibetan Review: The Monthly Magazine on all Aspects } \\
\text { of Tibet }\end{array}$ & 1 \\
\hline Environment and Planning D-Society \& Space & 1 & $\begin{array}{l}\text { Urban Anthropology \& Studies of Cultural Systems \& } \\
\text { World Economic Development }\end{array}$ & 1 \\
\hline Total & 73 & & 36 \\
\hline
\end{tabular}

published), but they are still very important for China's tourism development.

A keyword analysis was also conducted. Apart from 'China' and 'tourism', the most frequent keywords were 'tourism development' and an article focus on the development of China's tourism industry (Table 8). 'Management' appeared nine times, and these articles related to the management of China's tourism development. The third-ranked keywords were 'ecotourism' and 'travel', indicating interest in the development of eco-friendly tourism and travel in China. 'Development' ranked fourth, highlighting the significant academic interest in development. In the fifth and sixth rankings were keywords such as 'sustainable development', 'low-carbon tourism', 'model', 'international tourism (mostly meaning outbound tourism)', 'community participation', 'authenticity' and 'tourism policy'. These articles focused on the prospects for repositioning or adjusting China's tourism development. 'Attitudes' and 'heritage tourism' were in research studies on resident attitudes toward the fast development of China's tourism.

In the ranking of the keywords, the countries and regions that were most mentioned included China (Mainland), Hong Kong and Australia, which has strong connections with China. Some famous Chinese destinations such as Lijiang, Shanghai and Xiamen were most frequently specified in these articles.

\section{Trends and research gaps}

The final research objective was to detect trends in research themes and topics. Research on tourist markets is experiencing a growth trend, whereas research on policy and impacts excluding ecological impact research appears to be declining. In particular, the spotlight of research on China's tourism seems to be shifting away from policy toward aspects of tourism development and tourist markets. However, most of the research articles on China's tourism still focus on supplyside aspects, and demand-side articles are still in the minority. 
Table 4. Author article productivity

\begin{tabular}{lccl}
\hline Rank & $\begin{array}{c}\text { Frequency of } \\
\text { author name }\end{array}$ & $\begin{array}{c}\text { Number of } \\
\text { authors }\end{array}$ & \multicolumn{1}{c}{ Author names } \\
\hline 1 & 14 & 1 & Wall, G. \\
2 & 11 & 2 & Ryan, C.; Zhang, H. Q. \\
3 & 7 & 1 & Huang, S. S. \\
4 & 6 & 3 & Gu, H. M.; Law, R.; Bao, J. G. \\
5 & 5 & 7 & Li, Y. P.; Liu, J.; Hsu, C. H. \\
& & & C.; Su, X. B.; Wang, Y.; \\
& & & Zhang, G. R.; Zhang, J. \\
6 & 46 & Pan, G. W.; Song, H. Y.; \\
& & & Wong, K. K. F.; Heung, V. \\
& & & C. S.; Tisdell, C.; Song, Z. \\
& & & B.; Deng, J. Y.; Xiao, H. G.; \\
& & Li, W. J.; Ding, P. Y.; Kim, \\
& & W. G.; Cai, L. P.; Liu, W.; \\
& & Wu, B. H.; Zhong, L. S.; Li, X.
\end{tabular}

This finding is consistent with the results from previous reviews of the literature on China's tourism.

Generally, when compared with the international research on other geographic market sources, there seemed to be a lack of consumer behavior research on Chinese tourist markets. This may partly be attributable to weaker methodological skills among Mainland China's tourism researchers noted by Huang and Hsu (2008). In addition, there was not a great deal of articles with a focus on tourism or destination marketing. It is noteworthy here that there are no Chinese-language tourism and hospitality journals that have 'marketing' in their titles, whereas there are four such English-language journals (Journal of Travel \& Tourism Marketing, Journal of
Destination Marketing \& Management, Journal of Hospitality Marketing \& Management and Journal of Vacation Marketing). Also, there are other English-language journals, such as the Journal of Travel Research, that have a rich and long-standing tradition of publishing research on tourist consumer behavior. These observations indicate that tourism researchers based in China do not have as many academic journal venues available for research on tourist consumer behavior and other aspects of market research and marketing.

As tourism development accelerates in China, it is becoming an increasingly significant agent of change in the physical and social structures of local communities. There are increasingly frequent conflicts between residents and tourism with respect to the environment and land acquisition. There is a need for more research on how best to handle these contentious relationships between tourism and local communities. In particular, more research articles are needed on local resident attitudes and the impacts of tourism development on Mainland China communities. Although there has been growing worldwide attention on enhancing the quality of tourism services, the volume of literature on human resources (services) and education in Mainland China declined in proportionate terms, from 5 per cent of the articles in 1978-1990 to 3.7 per cent in 2011-2012. Moreover, this represented a very small amount of articles in comparison with the large volume of research published on quality, human resources and tourism education outside of Mainland China. Additionally, there were relatively few articles dealing with technology (4.8\%) and events and festivals $(1.8 \%)$ in comparison with those published abroad.

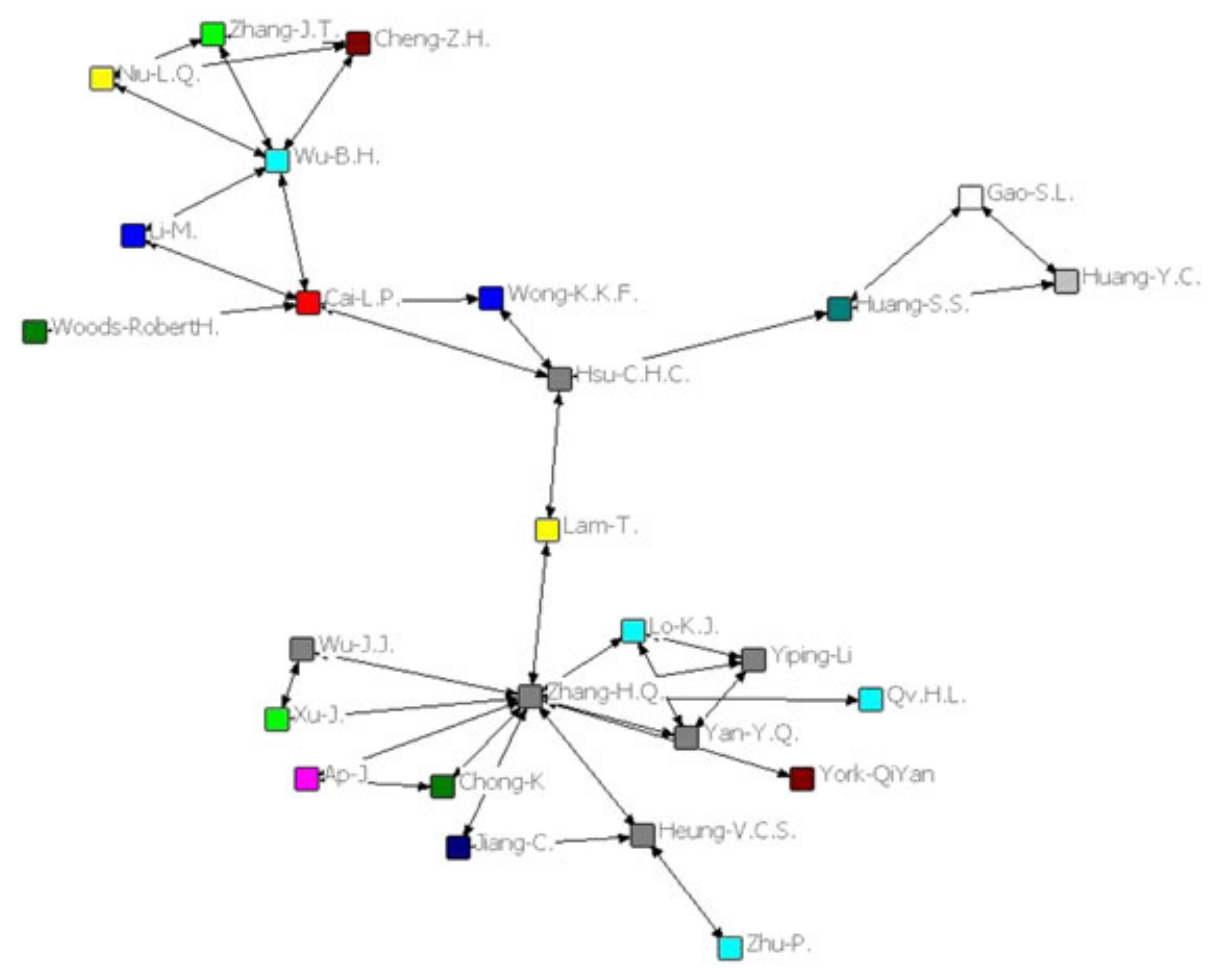

Figure 2. Authorship networks based on centrality metrics. 
Table 5. Regions of authors

\begin{tabular}{lcc}
\hline Region & Numbers & Rank \\
\hline Mainland China & 319 & 1 \\
USA & 156 & 2 \\
Hong Kong & 104 & 3 \\
Australia & 58 & 4 \\
Taiwan & 43 & 5 \\
UK & 38 & 6 \\
Canada & 37 & 7 \\
New Zealand & 18 & 8 \\
Singapore & 9 & 9 \\
The Netherlands & 6 & 10 \\
Japan & 5 & 11 \\
Korea & 4 & 12 \\
Macau & 4 & 12 \\
Germany & 3 & 14 \\
Spain & 3 & 14 \\
Belgium & 2 & 16 \\
Italy & 2 & 16 \\
Austria & 1 & 18 \\
France & 1 & 18 \\
Israel & 1 & 18 \\
Norway & 1 & 18 \\
Turkey & 1 & 18 \\
United Arab Emirates & 1 & 18 \\
Serbia & 1 & 18 \\
\hline
\end{tabular}

\section{CONCLUSIONS AND IMPLICATIONS FOR FUTURE RESEARCH ON CHINA'S TOURISM}

This study reviewed 333 research articles on China's tourism in 96 international academic journals from 1978 to 2012, to report on the status of research on China's tourism. These journals included not only tourism and hospitality journals but also other academic journals in business, marketing, sociology and other fields. Tourism Management, Annals of Tourism Research, International Journal of Hospitality Management and International Journal of Tourism Research were the tourism and hospitality journals publishing the most articles on China's tourism research. Research on China's tourism development dramatically increased after 2000; more than half of the articles were published from 2008 to 2012.

Most of the articles were sole-authored or had two authors. Among the 556 authors, 448 (80.6\%) contributed to only one article. The most productive author was Geoffrey Wall, who contributed to 14 articles. Other productive scholars included Chris Ryan, Hanqin Qiu Zhang, Huang Song Shan, Rob Law and Huimin Gu.

Twenty research topics belonging to three main themes were identified: tourist markets, tourism development and promotion, and tourism policy and impacts. Tourism researchers were mainly interested in topics such as tourism development, tourism policy, ecological impacts of tourism, tourism attractions and tourism promotion in China. These themes have attracted more attention in recent years. This study's results were highly consistent with those of Huang and Hsu (2008) in terms of the research themes and topics. This indicates that the research interests of China's tourism scholars are quite similar to scholars outside of Mainland China.

This study has named the journals that have a record of publishing full-length research articles on China's tourism. It also identified authors and most active research networks. The research topics on China tourism were pinpointed as were the trends in the popularity of topics. China's economic growth is sustaining and Chinese consumers are changing. Tourism scholars need to pay more attention to China by conducting further research in order to stay up-to-date with the development of China's tourism industry and markets.

The body of academic literature on China's tourism in journals is continuing to grow, and the focus of articles is gradually changing. However, the scholarship on China's tourism is not as diverse or as in-depth as for many others among the world's leading tourism destinations. Previous studies have attributed this to the early stage of China's tourism development, the realities of tourism within China and the greater influence of government in Mainland China. However, few have commented on the interests, capabilities and constraints of tourism scholars based in Mainland China when compared with tourism academics outside Mainland China. It is suggested that there are more constraints on the tourism scholars in Mainland China in terms of time and financial resources to pursue their own research agendas. Moreover, their academic backgrounds may be different than tourism scholars outside of Mainland China, leading to a different focus in research publications. It is also true that there are many more tourism and hospitality journals published in English than published in Chinese.

Language and cultural barriers pose a major problem in diffusing all of the research on China's tourism to the world outside of Mainland China, and likewise in exposing all of

Table 6. Author university affiliations

\begin{tabular}{llrr}
\hline Author university affiliations & Regions & Number of authors & Rank \\
\hline Hong Kong Polytechnic University & Hong Kong & 86 & 1 \\
Chinese Academy of Sciences & China & 47 & 2 \\
University of Waterloo & Canada & 28 & 3 \\
Sun Yat-sen University & China & 22 & 4 \\
Nanjing University & China & 18 & 5 \\
Michigan State University & USA & 17 & 6 \\
Peking University & China & 16 & 7 \\
Griffith University & Australia & 15 & 9 \\
Beijing International Studies University & China & 14 & 10 \\
University of Waikato & New Zealand & \\
\hline
\end{tabular}


Table 7. Research themes and topics of reviewed articles: 1979-2012

\begin{tabular}{|c|c|c|c|c|c|c|c|c|c|c|c|}
\hline Themes & Topics & 1978-1990 & $\%$ & 1991-2000 & $\%$ & 2001-2010 & $\%$ & 2011-2012 & $\%$ & Total & $\%$ \\
\hline \multirow[t]{7}{*}{ Tourist markets } & Behaviors & 1 & $5.0 \%$ & 1 & $3.0 \%$ & 8 & 4.7 & 4 & 3.7 & 14 & 4.2 \\
\hline & Markets & 1 & $5.0 \%$ & 1 & $3.0 \%$ & 12 & 7.0 & 8 & 7.4 & 22 & 6.6 \\
\hline & Flows & - & - & - & - & 3 & 1.7 & 2 & 1.9 & 5 & 1.5 \\
\hline & Segments & - & - & 1 & $3.0 \%$ & 5 & 2.9 & - & - & 6 & 1.8 \\
\hline & Motives & - & - & 1 & $3.0 \%$ & 4 & 2.3 & 3 & $2.8 \%$ & 8 & 2.4 \\
\hline & Images & 1 & $5.0 \%$ & 1 & $3.0 \%$ & 2 & 1.2 & 6 & $5.6 \%$ & 10 & 3.0 \\
\hline & Subtotal & 3 & $15.0 \%$ & 5 & $15.0 \%$ & 34 & 19.8 & 23 & $21.3 \%$ & 65 & 19.5 \\
\hline Tourism industry & Accommodation & 2 & $10.0 \%$ & 2 & $6.1 \%$ & 12 & 7.0 & 3 & $2.8 \%$ & 19 & 5.7 \\
\hline development and & Development & 4 & $20.0 \%$ & 4 & $12.1 \%$ & 22 & 12.8 & 19 & $17.6 \%$ & 49 & 14.7 \\
\hline \multirow{6}{*}{ promotion } & Attractions & - & - & 4 & $12.1 \%$ & 12 & 7.0 & 11 & $10.2 \%$ & 27 & 8.1 \\
\hline & Promotion & - & - & 2 & $6.1 \%$ & 10 & 5.8 & 3 & $2.8 \%$ & 15 & 4.5 \\
\hline & Services & 1 & $5.0 \%$ & 1 & $3.0 \%$ & 6 & 3.5 & 4 & $3.7 \%$ & 12 & 3.6 \\
\hline & Events & - & - & - & - & 4 & 2.3 & 2 & $1.9 \%$ & 6 & 1.8 \\
\hline & Food & - & - & - & - & 1 & 0.6 & - & - & 1 & 0.3 \\
\hline & Subtotal & 7 & $35.0 \%$ & 13 & $39.4 \%$ & 67 & 39.0 & 42 & $38.9 \%$ & 129 & 38.7 \\
\hline Tourism policy & Policy & 9 & $45.0 \%$ & 10 & $30.3 \%$ & 11 & 6.4 & 8 & $7.4 \%$ & 38 & 11.5 \\
\hline \multirow[t]{7}{*}{ and impacts } & Ecological impacts & - & - & 2 & $6.1 \%$ & 13 & 7.6 & 14 & $13.0 \%$ & 29 & 8.7 \\
\hline & Community & - & - & 1 & $3.0 \%$ & 11 & 6.4 & 5 & $4.6 \%$ & 17 & 5.1 \\
\hline & Education & 1 & $5.0 \%$ & 2 & $6.1 \%$ & 9 & 5.2 & 4 & $3.7 \%$ & 16 & 4.8 \\
\hline & Technology & - & - & - & - & 6 & 3.5 & 4 & $3.7 \%$ & 10 & 3.0 \\
\hline & Social impacts & - & - & - & - & 13 & 7.6 & 5 & $4.6 \%$ & 18 & 5.4 \\
\hline & Economic impacts & - & - & - & - & 8 & 4.7 & 3 & $2.8 \%$ & 11 & 3.3 \\
\hline & Subtotal & 10 & $50.0 \%$ & 15 & $45.5 \%$ & 71 & 41.3 & 43 & $39.8 \%$ & 139 & 41.8 \\
\hline Total & & 20 & $6.0 \%$ & 33 & $9.9 \%$ & 172 & 51.7 & 108 & $32.4 \%$ & 333 & 100.0 \\
\hline
\end{tabular}

Table 8. Ranking and frequencies of research keywords

\begin{tabular}{|c|c|c|}
\hline Rank & Frequencies & Keywords \\
\hline 1 & 13 & Tourism development \\
\hline 2 & 9 & Management \\
\hline 3 & 8 & Ecotourism and travel \\
\hline 4 & 7 & Development \\
\hline 5 & 6 & $\begin{array}{l}\text { Sustainable development, low-carbon tourism, } \\
\text { community participation, rural tourism and } \\
\text { authenticity }\end{array}$ \\
\hline 6 & 5 & $\begin{array}{l}\text { China, tourism policy, domestic tourism, } \\
\text { Hong Kong, motivation, heritage tourism, } \\
\text { model, attitudes, tourist attractions, hospitality } \\
\text { and international tourism }\end{array}$ \\
\hline
\end{tabular}

the China-based research published in English to the tourism scholars in Mainland China (Huang and Hsu, 2008; Tsang and Hsu, 2011). Breaking down these barriers is a future responsibility of both sets of scholars and their academic institutions. One of the ways is for more publishing networks to be developed involving tourism scholars within and outside of Mainland China.

\section{Limitations}

Although this research study analyzed 96 academic journals from the selected databases, still more journals could have been included in the review. There are now at least 75 English-language academic journals for tourism, hospitality and leisure, and this research only analyzed 24 of these journals. Some influential journals such as the Journal of China Tourism Research and Asia Pacific Journal of
Tourism Research were not included, and this was a limitation of the databases that were used. Future studies should expand the article reviewing scope by incorporating other influential tourism research journals to present a broader and more in-depth understanding. Moreover, this study only reviewed refereed articles published in Englishlanguage journals. The study did not and could not include papers published in languages other than English or hospitality and tourism books and conference proceedings. Further exploring the Chinese-language literature and other types of publications both in English and Chinese might offer additional insights.

This review only measured scholarship in quantitative terms and did not attempt to analyze the quality of the research. In addition, the method of counting multipleauthored papers may produce a distorted view in expressing author and regional productivity. Although these have been standard practices in the past reviews of research on China's tourism, it remains a distinct weakness of these collective works. Moreover, this study did not analyze or provide commentary on the research methodologies used in the articles.

Another limitation was the forcing of each article into one of 20 topic categories. Once again, although this has been a standard procedure in reviews of this kind, there are other alternative ways to classify the titles of articles. For example, each title can be sorted into two or more subtopics rather than just one. This allows for more freedom in article classification and may produce a richer set of results.

This research analyzed the productivity of tourism scholars solely in terms of academic journal articles, and this certainly has not been the only venue for publications. In 
China, the relationship between government agencies and academia is closer than in many Western nations, and leading academics such as Bao Jigang, Wu Bihu, Gu Huimin, Song Haiyan, Xu Honggen and others have been closely involved in the development of regional plans and the preparation of hotel benchmarking policies in ways not generally open to Western counterparts. Moreover, many scholars in Mainland China put a greater focus on book publishing than their counterparts abroad and it is somewhat simpler to publish such books in China.

\section{ACKNOWLEDGEMENT}

This project is partly supported by a research grant funded by Beijing International Studies University.

\section{REFERENCES}

Aramberri J, Xie Y. 2003. Multi-vision and China's tourism research: comment on the domestic and foreign relevant literature. Tourism Tribune 6(18): 14-20.

Australia Bureau of Statistics. 2013. Australia triples in popularity with Chinese and Indian visitors. Retrieved February 13, 2013 from http://www.abs.gov.au/ausstats/abs@.nsf/Latestproducts/ 3401.0Media\%20Release1Dec\%202012?

opendocument $\&$ tabname $=$ Summary $\&$ prodno $=3401.0 \&$ issue $=-$ Dec\%202012\&num $=\&$ view $=$

Baaijens SR, Nijkamp P, Van Montfort K. 1998. Explanatory metaanalysis for the comparison and transfer of regional tourist income multipliers. Regional Studies 32(9): 839-849.

Baum T. 2007. The changing face of human resource management in tourism and hospitality: a desert mirage? In McDonnell I, Grabowski S, March R (eds). CAUTHE 2007 - Past Achievements, Future Challenges. University of Technology Sydney: Sydney, N. S. W.; 764-782.

Borgatti, SP, Everett, MG and Freeman, LC. 2002. Ucinet for Windows: Software for Social Network Analysis. Harvard, MA: Analytic Technologies. China National Tourism Administration. 2002. China's tourism statistics bulletin 2001. Retrieved June 13, 2012, from http://www.cnta.gov.cn/

China National Tourism Administration. 2012. China's tourism statistics bulletin 2011. Retrieved June 13, 2012, from http://www. cnta.gov.cn/.

Cook RA, Yale LJ, Marqua JJ. 2010. Tourism: The Business of Travel. Prentice Hall: London.

Cooper CP. 2003. Classic Reviews in Tourism. Channel View Publications: Clevedon, UK.

Crawford WS, McCleary KW. 1992. An identification of the subject areas and research techniques used in five hospitality-related journals. International Journal of Hospitality Management 11(2): 155-167.

Crouch GI. 1995. A meta-analysis of tourism demand. Annals of Tourism Research 22(1): 103-118.

Dann G, Nash D, Pearce P. 1988. Methodology in tourism research. Annals of Tourism Research 15(1): 1-28.

Hsu C, Huang J, Huang S. 2010. Tourism and hospitality research in Mainland China: trends from 2000 to 2008. In Pearce D, Butler R (eds). Tourism Research: A 20:20 Vision. Goodfellow Publishers: Oxford, UK; 147-160.
Huang SS, Hsu CHC. 2008. Recent tourism and hospitality research in China. International Journal of Hospitality \& Tourism Administration 9(3): 267-287.

Jogaratnam G, Chon K, McCleary K, Mena M, Yoo J. 2005. An analysis of institutional contributors to three major academic tourism journals. Tourism Management 26(5): 641-648.

Kong HY, Cheung C. 2009. Hotel development in China: a review of the English language literature. International Journal of Contemporary Hospitality Management 21(3): 341-355.

Law R, Qi S, Buhalis D. 2010. Progress in tourism management: a review of website evaluation in tourism research. Tourism Management 31(3): 297-313.

Lew A, Yu L, Ap J, Zhang G. 2003. Tourism in China. Routledge: New York.

Li X, Harrill R, Uysal M, Burnett T, Zhan X. 2010. Estimating the size of the Chinese outbound travel market: a demand-side approach. Tourism Management 31(2): 250-259.

Miles MB, Huberman AM. 1994. Qualitative Data Analysis: An Expanded Sourcebook. SAGE Publications, Inc. Thousand Oaks, California

Park YA, Gretzel U. 2007. Success factors for destination marketing web sites: a qualitative meta-analysis. Journal of Travel Research 46(1): 46-63.

Pike S. 2002. Destination image analysis - a review of 142 papers from 1973 to 2000. Tourism Management 23(5): 541-549.

Pine R. 2002. China's hotel industry: serving a massive market. The Cornell Hotel and Restaurant Administration Quarterly 43(3): 61-70.

Ryan C, Gu H. 2009. Tourism in China: Destination, Cultures and Communities. Taylor \& Francis. Routledge: New York.

Sheldon PJ. 1991. An authorship analysis of tourism research. Annals of Tourism Research 18(3): 473-484.

Song Z, Wu Q, Lian Y, Yang F. 2005. Retrospect and prospect: tourism tribune from 2000 to 2004. Tourism Tribune 20(4): 80-84.

Statistics New Zealand. 2013. International visitor arrivals to New Zealand: December 2012. Retrieved February 13, 2013 from http://www.stats.govt.nz/browse_for_stats/population/Migration/international-visitor-arrivals-dec-12.aspx

Tsang NKF, Hsu CHC. 2011. Thirty years of research on tourism and hospitality management in China: a review and analysis of journal publications. International Journal of Hospitality Management 30(4): 886-896.

UNWTO. 2009. Tourism 2020 Vision Forecasts. World Tourism Organization: Madrid; 45-48.

Wang S, Bickle M, Harrill R. 2010. Residents' attitudes toward tourism development in Shandong, China. International Journal of Culture, Tourism and Hospitality Research 4(4): 327-339.

Weber K. 2001. Outdoor adventure tourism: a review of research approaches. Annals of Tourism Research 28(2): 360-377.

Weed M. 2009. Progress in sports tourism research? A metareview and exploration of futures. Tourism Management 30(5): 615-628.

Xie Y. 2003. Tourism and hospitality industry studies: a comparative research between China and the overseas countries. Tourism Tribune 5(18): 20-25.

Zhang L. 2004. Recent development of international tourism research: literature analysis for the Annals of Tourism Research. Tourism Tribune 19(3): 82-87.

Zhang G, Pine R, Zhang HQ. 2000. China's international tourism development: present and future. International Journal of Contemporary Hospitality Management 12(5): 282-290. 